\title{
Homeopathic complex increases survival without affecting the performance of Nile tilapia during masculinization
}

José Dias-Neto, Gustavo Moraes Ramos Valladão, Pedro Henrique De Oliveira Viadanna \& Fabiana Pilarski

To cite this article: José Dias-Neto, Gustavo Moraes Ramos Valladão, Pedro Henrique De Oliveira Viadanna \& Fabiana Pilarski (2017) Homeopathic complex increases survival without affecting the performance of Nile tilapia during masculinization, Journal of Applied Aquaculture, 29:1, 33-45, DOI: $10.1080 / 10454438.2016 .1274705$

To link to this article: https://doi.org/10.1080/10454438.2016.1274705

Published online: 11 Jan 2017.

Submit your article to this journal ¿

Џ Article views: 60

View Crossmark data ¿ 


\title{
Homeopathic complex increases survival without affecting the performance of Nile tilapia during masculinization
}

\author{
José Dias-Neto ${ }^{a}$, Gustavo Moraes Ramos Valladão $\mathbb{0}^{\mathrm{b}}$, \\ Pedro Henrique De Oliveira Viadanna ${ }^{\mathrm{b}}$, and Fabiana Pilarski ${ }^{\mathrm{b}}$ \\ aPreVet Sanidade Aquícola, Jaboticabal, São Paulo, Brazil; ${ }^{b}$ Aquaculture Center (CAUNESP), \\ Universidade Estadual Paulista (UNESP), Jaboticabal, São Paulo, Brazil
}

\begin{abstract}
During the masculinization of Nile tilapia, Oreochromis niloticus, the effect of a homeopathic complex (containing Chamomilla, Quina, and sulphur) was evaluated based on survival, performance, gills and liver integrity, and parasitism. Group fed with basal diet +17 alpha-methyltestosterone (control) showed low survival (40.02\%), while the group that additionally received homeopathy and the group that received sucrose (vehicle) showed $73.7 \%$ and $87.7 \%$ survival, respectively. The growth performance of the group that received homeopathic and the control group was significantly higher than that of the group that received only sucrose. Still, fish that received the homeopathic complex showed higher branchial and hepatic integrity as compared to the other groups. The homeopathic complex contributes to a greater survival of fish in addition to maintaining satisfactory growth. Furthermore, homeopathy contributes to the improvement in gill and liver integrity of the Nile tilapia larvae.
\end{abstract}

\section{KEYWORDS}

Aquaculture; Chamomilla;

Quina; sulphur; testosterone

\section{Introduction}

Diverse strategies are applied to animal production in search of maximum productivity. One of the most important strategies in fish farming around the world is the production of a monosex fish stock (Baroiller et al. 2009; El-Sayed 2006). The females of some species such as the rainbow trout Oncorhynchus mykiss exhibit better productive characteristics (Razmi et al. 2011). For others, the male is more suitable because of rapid growth and greater uniformity as seen in the Nile tilapia Oreochromis niloticus (Bwanika et al. 2007). The most common strategy of monosex tilapia production is through the administration (incorporation in the diet) of the hormone 17 alpha-methyltestosterone, which is a steroid structurally similar to natural testosterone, but with a methyl group at the C-17 position.

Considering that the hormone 17 alpha-methyltestosterone is an anabolic agent, the masculinized fish consequently show a higher weight gain (Karsli 
et al. 2014; Khalil et al. 2011; Vick and Hayton 2001). The survival, however, is significantly lower when compared to fish that receive diets without the hormone (Gayão et al. 2013). The decreased survival of fish larvae can be associated with the structural alterations of important organs such as the liver (Hasheesh et al. 2011), which is already overloaded by high protein and lipid content of the prepared diets (Furuya 2010), or can be associated with biochemical alterations (Ahmad et al. 2002; Hasheesh et al. 2011). These alterations can result in systemic diseases and facilitate the dissemination of opportunistic pathogens. The application of homeopathic products can support aquatic organisms against these challenges, since the use of homeopathy can provide conditions capable of promoting the homeostatic restoration of the organisms (Servais 2003) by rebound effect or secondary action (Teixeira 2013).

Homeopathy is an alternative medicine that causes the symptoms of a disease in healthy animals. This therapy has been used successfully in aquaculture (Merlini et al. 2014; Siena et al. 2010; Valentim-Zabott et al. 2008). The homeopathic complex is a set of homeopathic substances that act synergistically. Such a complex is usually composed of Chamomilla, Quina and sulphur. The Chamomilla is indicated for organisms that are sensitive to sudden temperature changes, for the control of fights (common in cichlids such as tilapia), against situations of stress, and intolerance to density (Brunini and Sampaio 1992; Cristea et al. 1997; Lathoud 2010). The Quina is a medicine used when a loss of body fluids, electrolyte disturbances, edema, and hemorrhages occur (Brunini and Sampaio 1992). The sulphur is recommended to treat injuries of the integument, such as parasitic diseases and irritations (Almeida et al. 2007), and has an important role in the venous circulation with great potency to prevent cases of edema (Lathoud 2010).

Based on this information, the potential beneficial effect of the homeopathic complex was evaluated by the survival, performance, branchial and liver integrity, and the prevalence of parasites during the masculinization phase of the Nile tilapia.

\section{Materials and methods}

\section{Infrastructure and fish}

The present study was conducted in a center of reproduction and fingerling production of the Nile tilapia (São Paulo, Brazil). The larvae (3-4 days old) were collected from reproduction ponds with ichthyoplankton fine-mesh nets and then stocked into nine experimental tanks. Each $750 \mathrm{~L}$ tank had a continuous water flow with total water renovation in $24 \mathrm{~h}$. The initial density in each tank was 1,000 larvae with an average total biomass of $18 \mathrm{~g}$. 
The water quality was monitored weekly using a multiparameter probe (YSI Professional Plus $\left.{ }^{\circ}\right)$. The dissolved oxygen $(\mathrm{OD})$, temperature $\left(\mathrm{T}^{\circ} \mathrm{C}\right)$, conductivity (EC), $\mathrm{pH}$, ammonia $\left(\mathrm{NH}_{4}\right)$, and the total dissolved solids (TDS) were measured. The parameters observed during the study were described as means (minimummaximum): $6.75 \mathrm{mg} / \mathrm{L}(4.54-7.61 \mathrm{mg} / \mathrm{L}) ; 22.5^{\circ} \mathrm{C}\left(19.3-25.2^{\circ} \mathrm{C}\right) ; 0.01 \mathrm{mS} / \mathrm{cm}$ (0.008-0.060 mS/cm); pH $6.54(\mathrm{pH} 5.33-7.08) ; 0.662 \mathrm{mg} / \mathrm{L}(0-4.1 \mathrm{mg} / \mathrm{L}) \mathrm{NH}_{4}$; $0.007 \mathrm{~g} / \mathrm{L}(0.005-0.390 \mathrm{~g} / \mathrm{L})$, respectively.

\section{Experiment and diet}

Three experimental groups in triplicate were divided randomly among the nine tanks. All groups received a prepared commercial diet formulated specifically for this species, with the addition of the masculinizing hormone 17 alpha-methyltestosterone $(60 \mathrm{mg} / \mathrm{kg}$; control) to simulate what currently occurs in the production of tilapias. One of the groups, however, received the homeopathic complex added in the control diet, and another group received the vehicle of the homeopathic complex (sucrose) added in the control diet.

The homeopathic complex Fator Pró-Digestão Inicial ${ }^{\circledR}$ was produced for the present study by Arenales Homeopatianimal laboratory (Brazil), with Quina $12 \mathrm{C}\left(10^{-24}\right)$, Camomila $12 \mathrm{C}\left(10^{-24}\right)$, and sulphur $12 \mathrm{C}\left(10^{-24}\right)$, which are respectively the component, centesimal potency, and dilution.

The homeopathic complex was diluted in water and incorporated in the diet according to the manufacturer recommendations ( $15 \mathrm{~g}$ of the product were used per $\mathrm{kg}$ of feed). The same procedure was performed for the group that received only the sucrose.

The masculinization step was carried out during the initial 40 days of feeding (powder feed) to simulate the most common strategy used in fish farms. After this period, all of the fish were fed the commercial feed, and the experiment was concluded at 120 days of feeding to perform the final biometric data collection on fish. The addition of the homeopathic complex and sucrose was carried out until day 70 .

The feeding trial (composition of artificial diet and feed management) are shown in Tables 1 and 2, respectively.

\section{Performance indices}

An initial biometrics was performed at day 0 and a final biometrics at day 120 was performed with all of the surviving fish from each treatment. The total length (using a ruler) and weight (using a balance) of the animals were measured in addition to the description of the survival. Once this experiment was carried out in a fish farm, the final harvest that depended on total fish handling was performed according to the availability and management of its activities. Therefore, performace indices were collected only on day 120 . 
Table 1. Composition (levels/kg of feed) of the experimental diets fed to Nile tilapia (Oreochromis niloticus) larvae and juvenile.

\begin{tabular}{lrr}
\hline Item & Larvae & Juvenile \\
\hline Humidity (max.) & $0.75 \mathrm{~g}$ & $0.67 \mathrm{~g}$ \\
Protein (min.) & $485 \mathrm{~g}$ & $440 \mathrm{~g}$ \\
Ether extract (min.) & $66 \mathrm{~g}$ & $80 \mathrm{~g}$ \\
Mineral material (max.) & $158 \mathrm{~g}$ & $121 \mathrm{~g}$ \\
Fibrous material (max.) & $16 \mathrm{~g}$ & $15 \mathrm{~g}$ \\
Phosphorous (min.) & $15 \mathrm{~g}$ & $15 \mathrm{~g}$ \\
Vitamin C (min.) & $800 \mathrm{mg}$ & $800 \mathrm{mg}$ \\
MOS* (min.) & $60 \mathrm{mg}$ & $60 \mathrm{mg}$ \\
\hline
\end{tabular}

*MOS: Manano-oligosacharides.

Table 2. Quantity and frequency of feeding the three experimental groups of Nile tilapia (Oreochromis niloticus).

\begin{tabular}{lccc}
\hline Day & Feed $(\mathrm{g}) /$ tank & Daily frequency & Feed $(\mathrm{g}) /$ day $/$ tank \\
\hline 0 & 0.2 & 7 & 1.4 \\
7 & 0.3 & 6 & 1.8 \\
14 & 0.6 & 5 & 3.0 \\
28 & 1.0 & 5 & 5.0 \\
37 & 2.0 & 5 & 10 \\
53 & 4.0 & 5 & 20 \\
\hline
\end{tabular}

Survival, weight gain, and feed conversion were described, which were calculated using the formulas: Weight Gain $(W G)=$ Final Weight - Initial Weight; Feed Conversion $=$ (Quantity of feed consumed throughout the experimental period $) \div$ WG; Survival $=$ (final number of fish $\div$ initial number of fish) $\mathrm{x} 100$.

\section{Branchial and hepatic histology}

Nine anesthetized fish from each treatment were euthanized by disruption of the spinal cord and collected per sampling (days 7, 14, 28, and 60). The animals were fixed in $10 \%$ formalin, dehydrated in increasing solutions of ethyl alcohol, diaphonized in xylene, and paraffin-embedded $\left(\mathrm{Merck}^{\odot}\right)$. The sections $(4 \mu \mathrm{m})$ were processed with a histology razor in an automatic microtome (Leica-RM 2155) and were stained with hematoxylin and eosin (HE). The description of the histopathology was performed by pairs of pathologists, expressed in a qualitative manner, and grouped in similar sets.

All of the histological slides were photographed (Nikon E200 ${ }^{\circ}$ in three different areas for each organ, sampling three times each specific structure per area (different sites, but the same area three times). Branchial structures (size of the lamellar edema, size of the interlamellar space, and diameter of the mucous cell) and liver structures (area of the vacuole of the hepatocyte, 


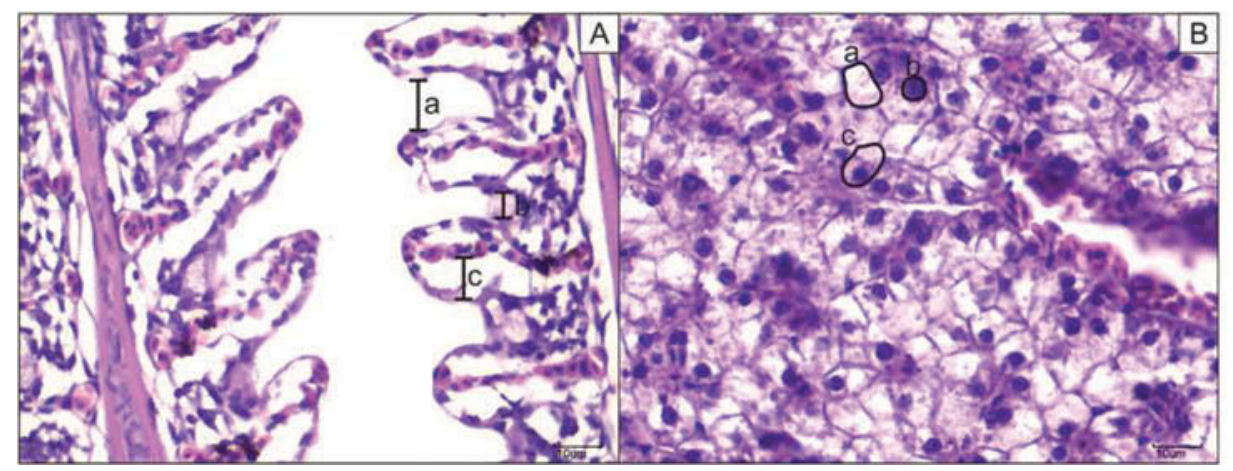

Figure 1. Histopathology standards used for measurements (H\&E stain). (A) Gills: interlamellar space (a), mucous cell diameter (b), and lamellar edema (c); (B) liver: area of vacuole of hepatocyte (a), area of the nucleus (b), and area of the hepatocyte (c).

area of the nucleus of the hepatocyte, and area of the hepatocyte) were measured manually and randomly using the software Image $J^{\oplus}$. All structures and the method of measurement are detailed in Figure 1.

\section{Parasitology analysis}

For parasitology analysis, nine fish were sampled from each treatment on days $7,14,28,60$, and 90 . In the first and second samplings, tissues of the animals were compressed between a slide and a cover slip to observe under an optical microscope, which permitted the total count of the parasites present. In the other samplings, due to the size, the animals were euthanized to collect the mucus of the skin and branchial biopsy.

Ectoparasites were identified by genus or group. The results were arranged in prevalence (\%) by the formula: (number of infected fish $\div$ number of fish analyzed) x 100.

\section{Statistical analysis}

Levene's test was used to analyze homoscedasticity, and one-way analysis of variance (ANOVA) followed by Tukey's test were used to collect parasitological and morphometric data of the liver and gills. The Mann-Whitney test, which was one tailed with a confidence interval of 95\%, and the Kruskal-Wallis ANOVA were used for the nonparametric data. The program STATISTIC $10^{\circ}$ Statsoft 1984-2011 and the GraphPad Prism 5 ${ }^{\circledR}$ program were used. 
Table 3. Performance of Nile tilapia (Oreochromis niloticus) fed with the commercial feed +17 alpha-methyltestosterone (CF), commercial feed +17 alpha-methyltestosterone + homeopathic complex $(\mathrm{CF}+\mathrm{Hp})$, and commercial feed +17 alpha-methyltestosterone + sucrose $(C F+\mathrm{S})$.

\begin{tabular}{lccc}
\hline & CF & CF $+\mathrm{Hp}$ & $\mathrm{CF}+\mathrm{S}$ \\
\hline Survival (\%) & 40.02 & 73.70 & 87.70 \\
Weight gain (g) & $9.27^{\mathrm{b}} \pm 4.56$ & $8.27^{\mathrm{b}} \pm 4.11$ & $6.75^{\mathrm{a}} \pm 4.34$ \\
Length $(\mathrm{cm})$ & $7.70^{\mathrm{b}} \pm 1.48$ & $7.50^{\mathrm{b}} \pm 1.48$ & $6.66^{\mathrm{a}} \pm 1.68$ \\
Feed conversion & $2.3: 1$ & $2.5: 1$ & $2.6: 1$ \\
\hline
\end{tabular}

Different letters represent significant difference between the treatments $(P<0.05)$.

\section{Results}

\section{Performance indices}

A higher survival was observed in the groups that received the homeopathic complex and the sucrose. Lower survival was observed in the control group that received only the diet with hormone 17 alpha-methyltestosterone. In relation to fish performance, weight gain and final length were higher in the control group and the group receiving the homeopathy. The group treated with the sucrose had a significant drop in performance compared to the other two groups $(P<0.05)$ (Table 3$)$.

\section{Branchial and hepatic histology}

Lamellar edema was the common histopathological alteration in the gills, while hydropic and lipid degeneration of the liver were described in all of the groups studied (Table 4).

The size of the lamellar edema did not differ significantly between the groups in any of the samplings $(P>0.05)$. The interlamellar space, however,

Table 4. Histopathologic alterations in the liver and the gills of Nile tilapia (Oreochromis niloticus) fed the commercial feed +17 alpha-methyltestosterone (CF), commercial feed +17 alphamethyltestosterone + homeopathic complex (CF $+\mathrm{Hp})$, and commercial feed +17 alphamethyltestosterone + sucrose $(C F+S)$ (descriptive analysis).

\begin{tabular}{|c|c|c|c|}
\hline & $\mathrm{CF}$ & $\mathrm{CF}+\mathrm{Hp}$ & $C F+S$ \\
\hline Organ & \multicolumn{3}{|c|}{ Day 7} \\
\hline Liver & $33 \% \mathrm{HD}$ & $67 \%$ HD; 33\% LD & $67 \%$ HD; 33\% LD \\
\hline Gill & $\begin{array}{l}100 \% \text { LE } \\
\text { Day } 14\end{array}$ & $100 \%$ LE & $100 \% \mathrm{LE}$ \\
\hline Liver & $50 \%$ LD; $50 \% \mathrm{HD}$ & $33 \%$ LD & $33 \% \mathrm{HD}$ \\
\hline Gill & $\begin{array}{l}100 \% \text { LE } \\
\text { Day } 28\end{array}$ & $100 \%$ LE & $100 \% \mathrm{LE}$ \\
\hline Liver & $71 \%$ HD; $29 \%$ LD & 87.5\% HD; $12.5 \%$ LD & $100 \%$ LD \\
\hline Gill & $\begin{array}{l}100 \% \text { LE } \\
\text { Day } 60\end{array}$ & 87.5\% LE & $50 \% \mathrm{LE}$ \\
\hline Liver & $33 \% \mathrm{HD} ; 67 \%$ LD & $12.5 \% \mathrm{HD} ; 87.5 \% \mathrm{LD}$ & $12.5 \% \mathrm{HD} ; 87.5 \%$ LD \\
\hline Gill & $87.5 \% \mathrm{LE}$ & $67 \% \mathrm{LE}$ & $89 \%$ LE \\
\hline
\end{tabular}

LD: lipid degeneration; HD: hydropic degeneration; LE: lamellar edema. 
was observed to be significantly higher on day 28 and thereafter in the group that received the homeopathic complex, and the difference increased on day $60(P<0.05)$. The area of the mucous cells was not influenced in any of the groups (Table 5).

In relation to the measurements in the liver, the size of the vacuole was significantly lower in the group that received the homeopathic complex when compared to the control group $(P<0.05)$ after 60 days of the experiment (Table 4). The nucleus of the hepatocyte was greater on days 7 and 28 in the group that received the sucrose when compared to the other two groups but was similar among all of the groups on day 14 and day 60 . The size of the hepatocyte was greater on days 7 and 14 in the fish that received the sucrose when compared to those who received the homeopathic complex, but neither differed from the control (Table 6).

\section{Parasitism}

Eight protozoa (Apiosoma, Chilodonella, Cryptobia, Ichthyobodo, Ichthyophthirius, Piscinoodinium, Trichodina, and Vorticella) and one metazoan (Monogenea) parasites were present in the larvae of the Nile tilapia in this study. The parasitism data behaved similarly among the three groups, with no statistical difference encountered $(P>0.05)$ for the prevalence of any species of the parasites in any of the samplings (Table 7 ).

\section{Discussion}

In the present study, a high mortality of larvae was observed in the group that received only the diet with the hormone 17 alpha-methyltestosterone ( $40 \%$ survival; control group). Despite also having received this hormone, the groups treated with the homeopathic complex and sucrose demonstrated a higher survival. Only the group that received homeopathy, however, had a performance (weight gain and final length) similar to that of the control group. The homeopathy group demonstrated higher survival and similar performance to the control group, which may be associated with the results obtained from the gill and liver analyses. Similarly, Siena et al. (2010) and Valentim-Zabott et al. (2008) also observed an increased survival in tilapia treated with the homeopathic complex. Stressors are related to high mortality rates (Barton and Iwama 1991; Tort 2011), which become exacerbated in fish subjected to masculinization. The increased survival of the animals that received the homeopathy, however, indicates a protective effect and demonstrates the homeopathy to be an alternative tool for fish farmers. Recently, Merlini et al. (2014) described a decrease of the cortisol levels in Nile tilapia treated with the homeopathic complex, which may be indicative of reduced levels of stress. 

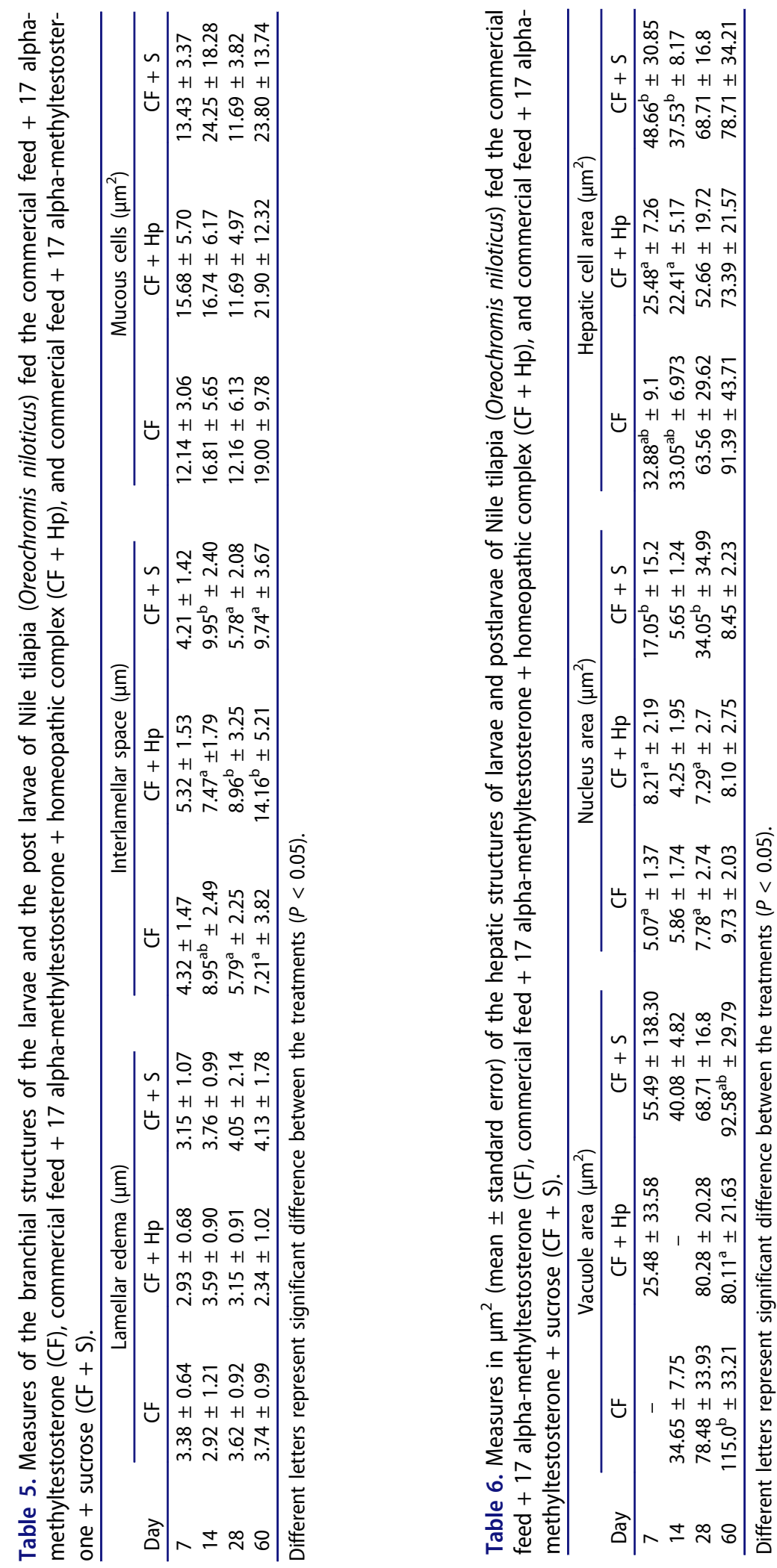


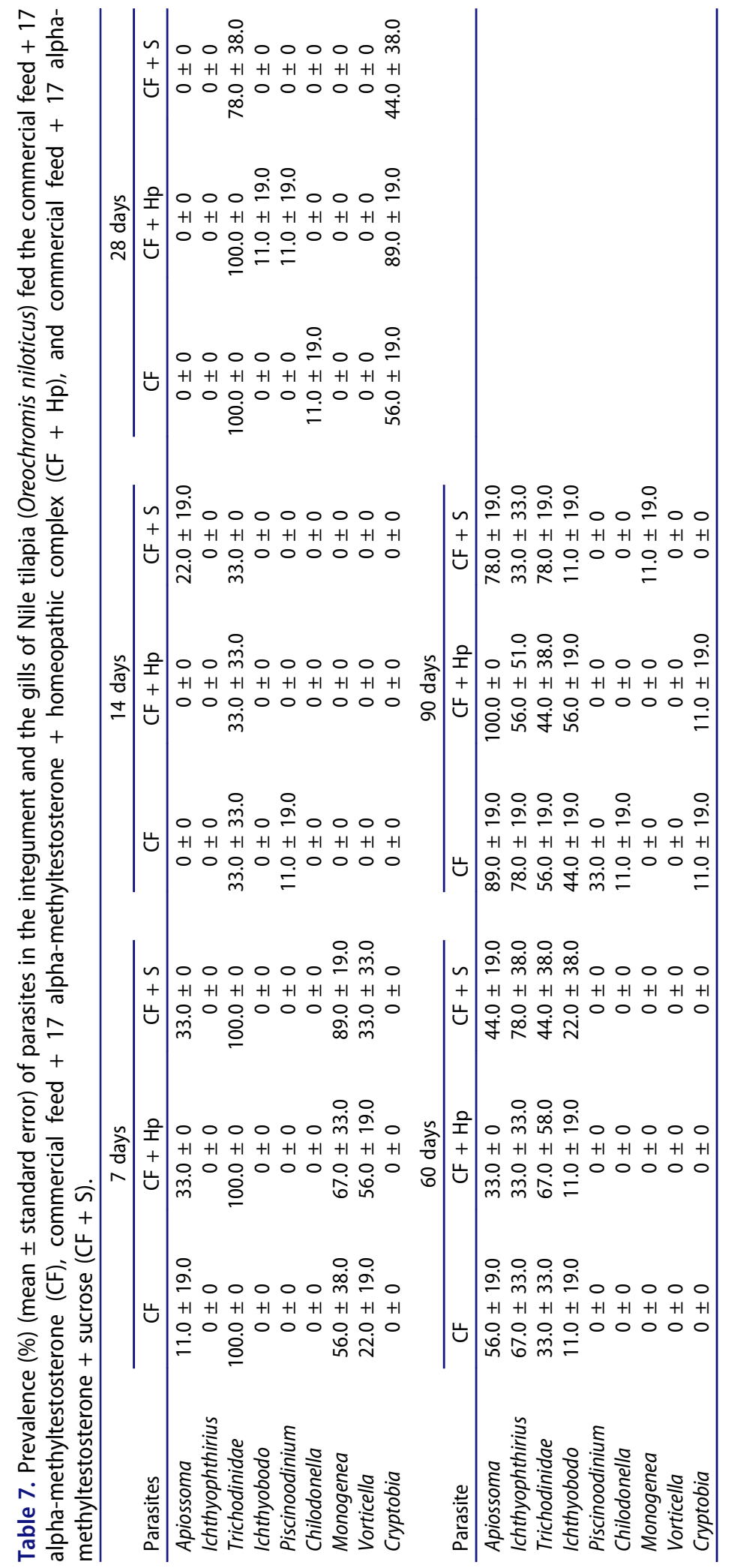


The gill is an organ often exposed to the aquatic environment. Toxic irritants, such as heavy metals, pesticides, disinfectants (Roberts 2012; Schwaiger et al. 1997) and parasites (Valladão et al. 2014) cause severe alterations in the gill structure, compromising the function of its filaments. The lamellar edema is the most common lesion in fish and can progress to necrosis of the lamellar epithelium, causing respiratory and osmoregulatory distress, which ultimately compromises the survival and the development of the fish (Yang and Albright 1992). Both control and sucrose groups showed a smaller spacing between the branchial lamellae, which indicates smaller surface area for gas and ion exchange. The surface area for gas and ion exchange is an important factor for the survival of sensitive animals such as fish larvae. Therefore, the fish from the homeopathic group showed more integrated branchial structure.

There is evidence that exogenous methyltestosterone and its metabolites are found in high concentrations in the gallbladder and liver of fish (Curtis et al. 1991; Goudie et al. 1986; Pandian and Kirankumar 2003). Thus, this organ is one of the main targets in these types of studies. Liver produces precursors of hormones, of the coagulation cascade, of the complement, in addition to producing globulins and lytic enzymes of the immune system (Kaneko 1997; Rouiller 2013). Alterations in this organ can lead to irreparable consequences and compromise the health of living organisms. The negative effect of the use of this steroid has been proven in the liver tissue of fish (Ahmad et al. 2002; Gayão et al. 2013; Hasheesh et al. 2011). The main liver alterations described in the literature are an increase of the cell volume, the disarrangement of the cordonal disposition, increase in vesicles in the hepatocytes (Gayão et al. 2013), diffused vacuolar degeneration, and congestion (Hasheesh et al. 2011). Furthermore, DNA fragmentation in the hepatic tissues of fish fed methyltestosterone were reported (Hasheesh et al. 2011; Khalil et al. 2011). In this study, the group of fish that received only the methyltestosterone showed a higher vacuolar size, suggesting that a larger area of the hepatic tissue can be compromised and less area is functional. The smaller size of hepatic vacuoles in the group that received the homeopathic complex indicates that the liver (usually overloaded by a diet rich in proteins and lipids) may be more functional and/or recover more quickly.

The homeopathy did not interfere in the prevalence of the parasites. In fact, the homeopathic complex, even with the sulphur, does not have parasiticide effect against any of the nine parasites of the fish in the present study. Despite this, the sulphur might have a protective effect on the microlesions or on the irritability of the animal faced with parasitism, since its pathogenesis is associated with alterations caused by parasites (Lathoud 2010). Similarly, Cavalcanti et al. (2007) observed that the homeopathic sulphur did not reduce nematode eggs in the feces of sheep; however, animals treated with the homeopathy showed no clinical signs of parasitic infection. Santos 
(2011) also observed that the sulphur did not alleviate the parasitism by the protozoan Amyloodinium sp. in cobia Rachycentron canadum; however, this medicine provided a protective action on the gills, which may have contributed to the greater fish survival. Still, Costa-Júnior, and Furlong (2011) described that the preventative effect of homeopathic preparations on parasitism demands long exposure periods to the product, which is not feasible because of the high cost.

The homeopathic complex contributes to a greater survival of fish, in addition to maintaining satisfactory growth. Furthermore, homeopathy contributes to the improvement in gill and liver integrity of the Nile tilapia larvae.

\section{ORCID}

Gustavo Moraes Ramos Valladão (D) http://orcid.org/0000-0002-3875-6247

\section{References}

Ahmad, M. H., A. M. E. Shalaby, Y. A. E. Khattab, and M. Abdel-Tawwab. 2002. Effects of 17 a-methyltestosterone on growth performance and some physiological changes of Nile tilapia fingerlings (Oreochromis niloticus L.). Egyptian Journal of Aquatic Biology and Fisheries 4(4): 295-311.

Almeida, L. R., F. S. Silva, A. H. Fonseca, J. P. G. Soares, and I. Lucke. 2007. Tratamento homeopático da infestação por Dermatobia homins (Linnaeus Jr., 1781) (Díptera: Cuterebridae) em bovinos sob manejo orgânico. Embrapa Agrobiologia, Seropédica. http://www.infoteca.cnptia.embrapa.br/infoteca/bitstream/doc/628325/1/ cot104.pdf.

Baroiller, J. F., H. d'Cotta, E. Bezault, S. Wessels, and G. Hoerstgen-Schwark. 2009. Tilapia sex determination: Where temperature and genetics meet. Comparative Biochemistry and Physiology Part A: Molecular \& Integrative Physiology 153:30-38. doi:10.1016/j. cbpa.2008.11.018.

Barton, B. A., and G. K. Iwama. 1991. Physiological changes in fish from stress in aquaculture with emphasis on the response and effects of corticosteroids. Annual Review of Fish Diseases 1:3-26. doi:10.1016/0959-8030(91)90019-G.

Brunini, C., and C. Sampaio. 1992. Matéria médica homeopática ibehe. São Paulo: Mythos.

Bwanika, G. N., D. J. Murie, and L. J. Chapman. 2007. Comparative age and growth of Nile tilapia (Oreochromis niloticus L.) in lakes Nabugabo and Wamala, Uganda. Hydrobiologia 589:287-301. doi:10.1007/s10750-007-0746-y.

Cavalcanti, A. D. S. R., M. A. O. D. Almeida, and A. V. S. Dias. 2007. Effect of homeopathic drugs on the numbers of nematode eggs in faeces (FEC) and on the body weight gain of sheep. Revista Brasileira de Saúde e Produção Animal 8:162-169.

Costa-Júnior, L. M., and J. Furlong. 2011. Efficiency of sulphur in garlic extract and nonsulphur homeopathy in the control of the cattle tick Rhipicephalus (Boophilus) microplus. Medical and Veterinary Entomology 25:7-11. doi:10.1111/mve.2011.25.issue-1.

Cristea, A., S. Teodorescu-Negres, and V. Darie. 1997. Chamomilla homeopathic dilution effect on central nervous system. In Signals and images, ed. M. Bastide, 171-178. Dordrecht, the Netherlands: Kluwer. 
Curtis, L. R., F. T. Diren, M. D. Hurley, W. K. Seim, and R. A. Tubb. 1991. Disposition and elimination of $17 \alpha$-methyltestosterone in Nile tilapia (Oreochromis niloticus). Aquaculture 99:193-201. doi:10.1016/0044-8486(91)90298-L.

El-Sayed, A. F. M. 2006. Tilapia culture. Cambridge, MA: CABI Publishing.

Furuya, W. M. 2010. Tabelas brasileiras para a nutrição de tilápias. Toledo, Brazil: GFM.

Gayão, A. L. B. A., H. Buzollo, G. C. Fávero, A. A. Silva-Junior, M. C. Portella, C. Cruz, and D. J. Carneiro. 2013. Hepatic histology and cage production of Nile tilapia hormonally masculinized or nonmasculininized. Pesquisa Agropecuária Brasileira 48:991-997. doi:10.1590/S0100-204X2013000800026.

Goudie, C. A., W. L. Shelton, and N. C. Parker. 1986. Tissue distribution and elimination of radiolabelled methyltestosterone fed to adult blue tilapia. Aquaculture 58:227-240. doi:10.1016/0044-8486(86)90088-8.

Hasheesh, W. S., M. A. S. Marie, H. H. Abbas, M. G. Eshak, and E. A. Zahran. 2011. An evaluation of the effect of $17 a$-methyltestosterone hormone on some biochemical, molecular and histological changes in the liver of Nile Tilapia; Oreochromis niloticus. Life Science Journal 8:343-358.

Kaneko, J. J. 1997. Clinical biochemistry of domestic animals. San Diego, CA: Academic Press. Karsli, Z., O. Aral, and N. Yeşilayer. 2014. The effects of different proportions of the $17 \beta$ estradiol and $17 \alpha$-methyltestosterone on growth, sex reversal and skin colouration of the electric blue hap (Sciaenochromis ahli Trewavas, 1935). Aquaculture Research 47(2): 640648. doi:10.1111/are.12524.

Khalil, W. K., W. S. Hasheesh, M. A. S. Marie, H. H. Abbas, and E. A. Zahran. 2011. Assessment the impact of $17 \alpha$-methyltestosterone hormone on growth, hormone concentration, molecular and histopathological changes in muscles and testis of Nile tilapia; Oreochromis niloticus. Life Science Journal 8:329-343.

Lathoud, J. A. 2010. Estudos de matérias médicas homeopáticas. São Paulo: Organon. [in Portuguese].

Merlini, L. S., L. Vargas, R. Piau, R. P. Ribeiro, and N. B. Merlini. 2014. Effects of a homeopathic complex on the performance and cortisol levels in Nile tilapia (Oreochromis niloticus). Homeopathy 103(2): 139-142. doi:10.1016/j.homp.2013.08.005.

Pandian, T. J., and S. Kirankumar. 2003. Recent advances in hormonal induction of sexreversal in fish. Journal of Applied Aquaculture 13:205-230. doi:10.1300/J028v13n03_02.

Razmi, K., T. Naji, M. Alizadeh, and H. Hoseinzadeh-Sahafi. 2011. Hormonal sex reversal of rainbow trout (Oncorhynchus mykiss) by ethynylestradiol-17a (EE2). Iranian Journal of Fisheries Sciences 10:304-315.

Roberts, R. J. 2012. Fish pathology. Hoboken, NJ: Wiley-Blackwell.

Rouiller, C. 2013. The liver: Morphology, biochemistry, physiology. New York: Academic Press.

Santos, B. G. 2011. Uso do medicamento homeopático Sulphur no controle do Amyloodinium sp. Brown (1931) em bijupirá (Rachycentron canadum) Linnaeus, 1766). Master's dissertation (Mestrado em Ciência Animal nos Trópicos), Escola de Medicina Veterinária, Universidade Federal da Bahia, Salvador, Brazil.

Schwaiger, J., R. Wanke, S. Adam, M. Pawer, W. Honnen, and R. Triebskorn. 1997. The use of histopathological indicators to evaluate contaminant-related stress in fish. Journal of Aquatic Ecosystem Stress and Recovery 6:75-86. doi:10.1023/A:1008212000208.

Servais, P. M. 2003. Larousse da homeopatia. São Paulo: Larousse.

Siena, C. E., M. R. M. Natali, G. L. Braccini, A. C. Oliveira, R. P. Ribeiro, and L. Vargas. 2010. Effect of core homeopathic homeopatila $100^{\circ}$ in productive efficiency of fingerlings reverted from Nile tilapia (Oreochromis niloticus). Semina: Ciências Agrárias 31:985-994. 
Teixeira, M. Z. 2013. Immunomodulatory drugs (natalizumab), worsening of multiple sclerosis, rebound effect and similitude. Homeopathy 102(3): 215-224. doi:10.1016/j.homp.2013.05.001.

Tort, L. 2011. Stress and immune modulation in fish. Developmental \& Comparative Immunology 35(12): 1366-1375. doi:10.1016/j.dci.2011.07.002.

Valentim-Zabott, M., L. Vargas, R. P. R. Ribeiro, R. Piau, M. B. A. Torres, M. Rönnau, and J. C. Souza. 2008. Effects of a homeopathic complex in Nile tilapia (Oreochromis niloticus L.) on performance, sexual proportion and histology. Homeopathy 97:190-195. doi:10.1016/j. homp.2008.08.007.

Valladão, G. M. R., S. U. Gallani, S. B. Padua, M. L. Martins, and F. Pilarski. 2014. Trichodina heterodentata (Ciliophora) infestation on Prochilodus lineatus larvae: A host-parasite relationship study. Parasitology 141:662-669. doi:10.1017/S0031182013001480.

Vick, A. M., and W. L. Hayton. 2001. Methyltestosterone pharmacolinetics and oral bioavailability in rainbow trout (Oncorhynchus mykiss). Aquatic Toxicology 52(3-4): 177-188. doi:10.1016/S0166-445X(00)00146-6.

Yang, C. Z., and L. J. Albright. 1992. Effects of the harmful diatom Chaetoceros concavicornison respiration of rainbow trout Oncorhynchus mykiss. Diseases of Aquatic Organisms 14:105-114. doi:10.3354/dao014105. 